\title{
More than one meaning of "chain" in Food Chains, a documentary film
}

Film review by Jane Kolodinsky*

University of Vermont

Review of Food Chains, directed by Sanjay Rawal; executive producers Eva Longoria and Eric Schlosser (Fast Food Nation and Food Inc.). Limited release; also available at iTunes. Film's website: http://www.foodchainsfilm.com

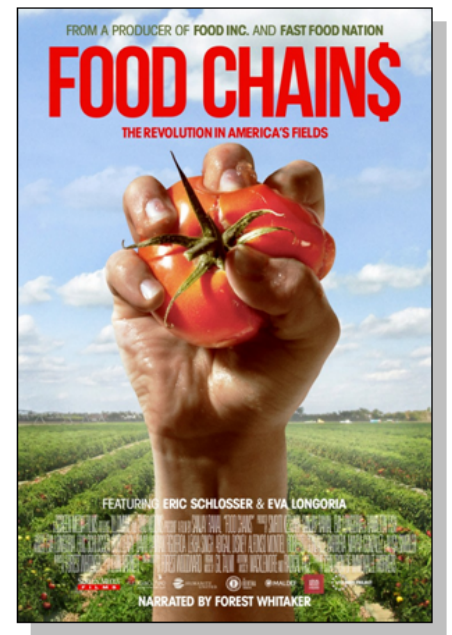

Published online December 10, 2014

Citation: Kolodinsky, J. (2014). There is more than one meaning of "chain" in Food Chains, a documentary film [Film review]. Journal of Agriculture, Food Systems, and Community Development, 5(1), 197-198.

http://dx.doi.org/10.5304/jafscd.2014.051.011

Copyright (C) 2014 by New Leaf Associates, Inc.

$\mathrm{O}$ n November 18, 2014, I had the opportunity to see an advance screening of Food Chains, a documentary from the producers of Fast Food Nation and Food, Inc. (It was released in the U.S. on November 21.) The film is about the long and arduous journey of the Coalition of Immokalee Workers (CIW) to win rights — basic rights - as farmworkers. The film was shown at the American Public Health Association (APHA) meetings in New Orleans, sponsored by the Food and Environment Working Group at APHA and hosted by Healthy Food Action. Worker rights have a lot to do with public health. But the film serves a much bigger audience. It can be used as a transdisciplinary starting point for discussion by scholars and practitioners in the food system who are interested in health, worker safety, food justice, labor laws, unlikely partners, and economic power and

* Jane Kolodinsky is professor and chair of the University of Vermont Department of Community Development and Applied Economics, and is director of the UVM Center for Rural Studies; Jane.Kolodinsky@uvm.edu concentration in the food industry.

When I received the invitation to review the film, I immediately thought of the book Nobodies: Modern American Slave Labor and the Dark Side of the New Global Economy (Bowe, 2008) which I read a few years ago and still recommend. I distinctly remembered the first chapter about slave labor in the tomato fields of Florida. Indeed, Food Chains is about the Immokalee workers of Florida, their struggles and successes, and the film included a segment on the slave-labor case that surfaced in 1997. Yes, 1997. That's 17 years before this film was released and just four years after the Immokalee workers began to organize. Particularly disturbing to me is the fact that after more than a decade since that slave-labor case surfaced, farmworkers are still fighting for basic worker rights... even basic human rights. These are the same workers, in the same tomato fields, suffering some of the same indignities. And while the CIW has some victories under its belt, we as a nation have a long way to go. 
Just as with Fast Food Nation, someone could write down a passage from The Jungle (Sinclair, 1906) and Food Chains and have about a 50-50 chance of a reader assigning the passage to the wrong source. Food Chains is a documentary; The Jungle is a novel. How can it be that more than a century after muckrakers exposed the deplorable conditions of workers in the food system, that harassment of workers, rapes in the fields, squalid living conditions, pesticide showers, hazardous working conditions, and slave wages continue be the norm? As the documentary highlights, the food industry goes out of its way to hide where our food comes from. After all, shopping wouldn't be such a pleasure if shoppers really knew about farmworker conditions.

A major initiative of the CIW is "a penny per pound." Workers have lobbied to have large purchasers of tomatoes pay just one penny more per pound. This would result, they say, in nearly doubling farmworkers' yearly incomes. Some major players have signed on, including Taco Bell and Trader Joe's. Publix, the largest supermarket chain in Florida and the store with the slogan "Where shopping is a pleasure," is a hold-out. A large portion of the film is dedicated to showing the hunger strike by workers and advocates in front of Publix's headquarters. The image of the strike, along with footage of field workers, makes the situation of farmworkers real to movie viewers. The goal of the strikers is the signing of the Fair Food agreement. To understand the significance of the Fair Food movement, we need to understand who the CIW is, and what signing a Fair Food agreement entails:

The Coalition of Immokalee Workers' (CIW) Fair Food Program is a unique partnership among farmers, farmworkers, and retail food companies that ensures humane wages and working conditions for the workers who pick fruits and vegetables on participating farms. It harnesses the power of consumer demand to give farmworkers a voice in the decisions that affect their lives, and to eliminate the long-standing abuses that have plagued agriculture for generations (Fair Food Program, n.d.). There is a twist to this film. Publix does not sign the Fair
Food agreement - but another giant food purveyor does. For some of us, that causes cognitive dissonance. In the arena of labor, and as the film points out, food giants are typically low-wage payers that compete on low prices that fuel the poor treatment of farmworkers. But in this film, one of the largest players is one of the heroes. The giant corporation buys into Fair Food. The film does not dwell on their signing of the agreement, nor does it place a lot of significance on it. After all, the documentary is about persuading Publix to sign on to fair food. Perhaps the film-makers suffered the same cognitive dissonance I did and did not know exactly how to portray the "bad guy gone good." It does make one think about strange bedfellows. We have to give some credit to the corporation that sells a lot of tomatoes to the consuming public because it means many more pennies per pound that increase farmworkers' incomes. You have to see the film to find out which food giant signed the Fair Food agreement. Personally, I never would have guessed.

The documentary is real, compelling, and a must-see. I know I will encourage student groups to screen it for our campus. Some people will cringe, some will make excuses, and some may look away. Regardless of the reaction, Food Chains will be a conversation starter. And, while my research into the film's claims confirmed the idea that it is the large supermarket and other chains that really have the power over farmworkers through their buying policies, there is no doubt that the word "chain" has a double meaning. Our abundant and cheap food policies in the U.S. have kept real chains on farmworkers.

\section{References}

Bowe, J. (2008). Nobodies: Modern American slave labor and the dark side of the new global economy. New York: Random House.

Fair Food Program. (n.d.). The Fair Food Program. Retrieved November 26, 2014, from http://www.fairfoodprogram.org/

Sinclair, U. (1906). The Jungle. New York: Doubleday, Page. 